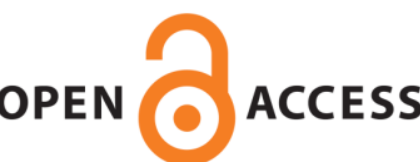

UWS Academic Portal

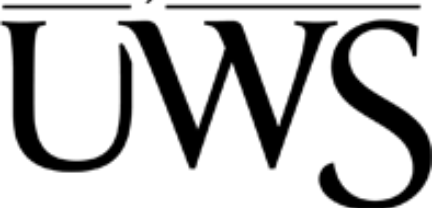

\title{
Mind the grass! Exploring the assessment of informant coverage in policing and law enforcement
}

Atkinson, Colin

Published in:

Journal of Policing, Intelligence and Counter Terrorism

DOI:

10.1080/18335330.2019.1572913

E-pub ahead of print: 15/02/2019

Document Version

Peer reviewed version

Link to publication on the UWS Academic Portal

Citation for published version (APA):

Atkinson, C. (2019). Mind the grass! Exploring the assessment of informant coverage in policing and law enforcement. Journal of Policing, Intelligence and Counter Terrorism, 14(1), 1-19.

https://doi.org/10.1080/18335330.2019.1572913

\section{General rights}

Copyright and moral rights for the publications made accessible in the UWS Academic Portal are retained by the authors and/or other copyright owners and it is a condition of accessing publications that users recognise and abide by the legal requirements associated with these rights.

Take down policy

If you believe that this document breaches copyright please contact pure@uws.ac.uk providing details, and we will remove access to the work immediately and investigate your claim. 
"This is an Accepted Manuscript of an article published by Taylor \& Francis Group in JOURNAL OF POLICING, INTELLIGENCE AND COUNTER TERRORISM on 15 February 2019, available online: http:// www.tandfonline.com/10.1080/18335330.2019.1572913." 


\title{
Mind the grass! Exploring the assessment of informant coverage in policing and law enforcement
}

\begin{abstract}
The use of informants, or Covert Human Intelligence Sources (CHIS), has become a mainstay of contemporary policing and law enforcement in the United Kingdom as police, security and enforcement agencies seek to tackle a range of crimes. Recognising the relative paucity of enquiry on this subject, and addressing the associated requirement for further empirical research, this paper explores how 'informant coverage' - the extent to which informants can provide information on targets, suspects, crimes, and criminal conspiracies - is assessed in policing and law enforcement in Scotland. It is principally informed by qualitative research conducted in 2017 and 2018, comprised of semi-structured interviews with 19 participants. Drawing upon a thematic analysis of the resultant data, and enriched by the author's prior experience as a practitioner in this field, this paper identifies the strengths and limitations of established practices. Additionally, this paper highlights the emerging role of analysis, and the contribution of the intelligence analyst, in this specialist area of intelligence work. It concludes that if analysis is to make a valuable and continuing contribution to the effective use of informants in future practice then sustained proactive leadership will be required to support such innovative approaches.
\end{abstract}

\section{Keywords}

Informants, covert policing, intelligence, analysis

\section{Introduction}

Informants are recruited by policing and law enforcement agencies to provide information on particular subjects, persons, or other entities of investigative interest. Within such agencies informants are oftentimes referred to as agents or 'sources' (Ingle and Staniforth, 2017: 124). Outside of such fields, and especially amongst the criminal fraternity, informants are pejoratively termed grasses, touts, snitches, or rats. From this rich and varied vernacular Ben Fitzpatrick (2009) has highlighted the emergence of the specific legislative term Covert Human Intelligence Source (CHIS); a new nomenclature that Charl Crous (2009) has suggested is indicative of the modernisation and professionalisation of police-informant relationships. Certainly in the United Kingdom (UK) the management of informants in policing and law enforcement has been subject to important and transformative processes of regulation and professionalisation over the past two decades, particularly following the reporting of a thematic inspection in 1999 (Williamson and Bagshaw, 2001: 54) and the introduction of legislation in 2000. In the period since the use of informants has become increasingly embedded in everyday practice across an array of agencies, within but also beyond policing and law enforcement, in order to tackle a range of crimes and offences.

Despite the long-held proclivity by police and law enforcement agencies to use covert human informants (Innes, 2000: 358; Schreiber, 2001: 301) academic inquiry in this area remains relatively circumscribed, not least due to the difficulties of researching this hidden area of policing (see Norris and Wilson, 2016). As Basia Spalek (2014: 831) has succinctly asserted, research into the role and use of CHIS is rare. Whilst such a situation is understandable, given the challenges of access (see Norris and Wilson, 2016), it is nonetheless lamentable given the attention initially afforded to this topic in some of the pioneering texts of police studies (see Manning, 1977; Skolnick, 2011). Addressing this paucity of research this paper offers a new perspective on the use of informants in Scottish policing and law enforcement by exploring the practices and approaches used to understand informant coverage', or the extent to which informants can provide information on the suspects, cases, crimes, and criminal conspiracies that are of interest to such agencies. Principally informed by qualitative research conducted in 2017 and 2018, and enriched by the author's prior experience as a practitioner in this particular field, this paper identifies the strengths and limitations of established practices in the 
assessment of informant coverage. Additionally, it highlights the emerging role of analysis, and the contribution of the intelligence analyst, in this specialist area of intelligence work. It concludes that if analysis is to make a valuable and continuing contribution to future practice then proactive and sustained leadership will be required to support such innovative practice. However, before developing such arguments this paper begins with an overview of the literature on this topic and a subsequent description of the particular research methods used to produce the findings.

\section{Literature review}

The available literature is clear that the use of informants in policing has a long history (see Clark, 2007: 431; Shane, 2016: 2) across a variety of jurisdictions: from the United States (US) and Canada (see Bloom, 2002; Wool, 1985) to Mexico and the UK (see Fondevila, 2013; Innes, 2000). The use of informants has particularly featured in the 'house of high-policing' (Sheptycki, 2007), where this tactic has been successfully deployed against networks implicated in terrorism and organised crime for some considerable time (see Bean and Billingsley, 2001; Moran, 2010; Charters, 2012; Cochrane and Monaghan, 2012). ${ }^{1}$ In fact the use of human informants in such fields is considered 'typical' (Manning, 2016: 25). Police intelligence work, within which police informant work is situated, has been extensively explored in scholarly research over the past two decades, covering an array of settings (see Gill, 1998; Sheptycki, 2004; Ratcliffe, 2002, 2005 and 2016). Within this body of research the covert and secretive sub-field of police informants has featured only infrequently (see, for examples, Miller, 2011; Loftus and Goold, 2012; James, 2016; Loftus, Goold and Mac Giollabhui, 2016), despite a recent call to look deeper inside police organisations that practice intelligence-led policing (Burcher and Whelan, 2018). This situation reflects a broader malaise in the study of covert policing, despite its growing importance (Mac Giollabhuí, Goold and Loftus, 2016: 631). Yet whilst there has been an upturn in both the use of informants and research on this subject since the turn of the millennium, it remains difficult to challenge the contention that social scientists have 'largely ignored' the role of informants in policing and law enforcement (see Miller, 2011).

The existing literature on informants in policing and law enforcement exhibits a particular focus on the ethical and legislative issues associated with this tactic (see Cooper and Murphy, 1997; Omand, 2006; Gill, 2009; Harfield, 2009; MacVean and Neyroud, 2012). Such typical treatments have not been limited to the UK; across the Atlantic John Shane's recent study on confidential informants (Cls) in the US - $\mathrm{Cl}$ being a broadly analogous American nomenclature for CHIS - remarked,

Using $\mathrm{Cls}$ has been explored from the legal, ethical, and theoretical perspectives, but none has examined actual police policy to see how $\mathrm{Cls}$ are managed by law enforcement agencies. (Shane, 2016: xvii).

The current UK legislative framework - manifest in the Regulation of Investigatory Powers Act 2000 (RIPA) and the Regulation of Investigatory Powers (Scotland) Act 2000 (RIP(S)A) - provides the legitimacy and statutory footing for both high and low policing actors to legally use informants in intrusive surveillance operations (Williamson, 2008: 3). The introduction of this legislative regime has been broadly received positively in contributing to the professionalisation of police informant work. Yet it has also been critiqued for increasing the 'bureaucratic burden' on practitioners, particularly as a result of the requirement for formal authorisation processes and independent external oversight of informant recruitment and handling (Matchett, 2017: 45). Similar sentiments were recorded by Bacon (2016: 191-195) in his ethnography of detectives in England, where risk assessments and authorisation

\footnotetext{
${ }^{1}$ For Jean-Paul Brodeur (2007: 27-28) high policing is characterised by the wide scope and strategic use of intelligence, the conflation of separate state powers, the protection of national security, and the use of informants and undercover operatives. Low policing, somewhat analytically neglected in comparison, refers to policing in the Peelian tradition: the consensual maintenance of order and suppression of street-based crime using preventive patrol by uniformed officers visible to the community.
} 
procedures caused delays in the communication of intelligence, resulting in 'missed opportunities and wasted resources'. ${ }^{2}$ Additionally, reflecting processes of the pluralisation of policing, the introduction of this new legislative framework for the legal use of informants in the UK has diversified the range of agencies now authorised to adopt this tactic. This is apparent in the capability of other relevant public authorities beyond policing, law enforcement and security agencies - for example local councils (see Clark, 2007: 435) - to deploy informants as specified in the legislation and the pursuant code of practice (Home Office, 2018). Tim Newburn (2011: 5) noted that the introduction of RIPA extended surveillance powers to more than 900 agencies beyond the police. Whilst such a development challenges the previously posited assertion by Billingsley (2003: 59) that policing and law enforcement has 'a monopoly on the business of informing', it is nonetheless notable that the uptake of the use informants by other public authorities has been limited in comparison (see Office of Surveillance Commissioners, 2016: 15).

Although law and ethics have featured prominently in research to date it must be recognised that a subset of studies - covering a range of jurisdictions, but particularly in the US, Australia, and in the UK - has discussed the day-to-day practice of police informant work and the use of this tactic in policing operations (see Innes, 2000; Billingsley, 2009a and 2009b; Crous, 2009, 2011; Rajakaruna et al, 2013; Lowe, 2015; Bacon, 2016; Dabney and Tewksbury, 2016). The insights from these studies have been compelling. For example, in a study published at a time when police informant work in the UK was becoming increasingly professionalised Martin Innes (2000) noted moves towards organisational and cultural change in the recruitment and management of informants,

Informants were [previously] a personal resource, attached to individual officers and their identity was jealously guarded... There has been a concerted effort within the senior ranks of the police service, to try and move away from this individualistic ethos, towards a more systematic organisation of detective work. This has been made concrete in some of the changes that have been introduced in the system for managing informants... [Chief officer] ranks have been particularly keen to make informants a resource for the whole police service rather than individual officers. (Innes, 2000: 370).

Drawing upon research evidence from all three of these particular jurisdictions David Lowe (2015) moved beyond the confines of law and ethics to engage with the everyday practicalities of informant recruitment and handling, including an appreciation of the motives and incentives to inform. Lowe also reflected upon the risks associated with informant work in policing and law enforcement, including corruption and the unethical handling of informants in Northern Ireland during 'the Troubles'. ${ }^{3}$ In the particular context of informant work in Australian policing, but with wider resonance elsewhere, Charles Crous (2011) recognised the importance of continuous training at all levels, alongside a level of intrusive supervision, in order to ensure that those officers responsible for dealing with informants at the level of everyday practice adhere to the processes, policies and governance arrangements that regulate this area of intelligence work. Such insights are valuable, and the following research develops further this focus on everyday practice.

\section{Research method}

This paper explores the various ways in which informant coverage is, and has recently been, assessed across Scottish policing and law enforcement. Reflecting that the bulk of research on everyday practice has explored the informant phenomenon from the perspective of law enforcement practitioners (see

\footnotetext{
${ }^{2}$ An ethnographic approach is not necessarily new in this field. Martin Innes' pioneering study at the turn of the millennium, for example, demonstrated the value of combining ethnography, interview, and secondary data analysis to examine the role of police informants in crime investigation (Innes, 2000).

${ }^{3}$ The Troubles was a period of intense low-level conflict in Northern Ireland between rival terrorist groups and British forces lasting from the mid to late-1960s until the early to mid-1990s (see Bell, 1993; Coogan 1996).
} 
Dabney and Tewksbury, 2016: 10) this study is principally informed by data from semi-structured interviews with 19 participants from policing and law enforcement agencies in Scotland conducted in 2017 and 2018. ${ }^{4}$ Issues of sampling strategy and access to participants loom large over any research design that is reliant on qualitative research. This is particularly relevant in policing, a subject of criminological interest that has been classically considered as one that erects barriers against 'prying outsiders', thus rendering it one of the most secluded parts of the criminal justice system (Punch, 1979: 4). Identifying and accessing research participants in policing can be challenging, given that such a 'service' is, in fact, a heterogeneous set of agencies and units that vary in their structures, cultures and functions; and a challenge compounded when one seeks to engage with the more sensitive and covert aspects of police intelligence work. Peter Manning (1978: 244), for example, has noted that police agencies are 'segmented, specialised and covert to a striking degree', and within this labyrinthine landscape the most hidden, sensitive, and closely guarded areas of policing can oftentimes be physically off-limits to the academic researcher (see Mac Giollabhuí, Goold and Loftus, 2016: 633). ${ }^{5}$

To overcome such challenges and identify participants for interview the researcher exploited his previous practitioner background and existing professional networks to negotiate access to police officers, law enforcement professionals and intelligence analysts currently working in this area of Scottish policing and law enforcement, as well as those who have recently retired or moved on from such positions but who retain deep knowledge of police informant work and the challenges therein. Such an approach is not without precedent, with the value of the insights and experiences of retired police officers evident in police research across a range of jurisdictions and subjects (see as examples, Cummings, Foley and King, 2014; Eterno, Verma and Silverman, 2016). The outcome of this overall convenience sampling procedure resulted in the undertaking semi-structured qualitative interviews with 19 serving or recently retired practitioners with experience of police informant work in Scotland. The participants were identified due to their expertise across a range of professional roles and responsibilities in this area of policing and law enforcement, including direct recruitment and contact with informants, coordination and supervision of this work, desk-based analysis of informants and the intelligence that informants produce, and those senior managers who oversee the use of informants and are accountable for the delivery of the strategic outcomes of their own particular agency. The data produced through these interviews were transcribed by the researcher where ethically and practically possible, with data imported into the NVivo qualitative data analysis software package for coding and subsequent thematic analysis. This thematic analysis informs the bulk of this paper, which explores both established and emerging practices in how informant coverage is appraised and understood in policing and law enforcement.

As with much qualitative research, there are limits on the generalisability of the findings of this study beyond the wider population with which it directly engages. The research captures developments in Scotland in the post-RIP(S)A landscape, and given the similar legislative context it is likely to provide some useful insights for policing and law enforcement elsewhere in the UK. Broader international comparisons may be more difficult to sustain due to the particular legislative, organisational and cultural underpinnings of police informant work in Scotland; but as an exploratory study that engages an under-researched topic the findings will be of interest to, and are likely to resonate with, a broad range of practitioners and scholars. Overall, this paper addresses, at least in part, the long-standing and still relevant call for the rigorous, research-based, study of the practical aspects of police informant work, and the processes and methods that underpin current systems (Billingsley, Nemitz and Bean, 2001: 22-23).

\footnotetext{
${ }^{4}$ For an example of research that reports and reflects upon on the activities from the perspective of an informant in the US see the work of Miller and Selva (1994). Also see the more recent work of Miller (2011) in which he draws upon data obtained from in-depth interviews with eighty-four former informants in the US.

${ }^{5}$ For some this justifies the use covert research methods in such settings (see Lowe, 2011); although more recent research demonstrates the possibilities for overt research (see Bacon, 2016).
} 


\section{Assessing informant coverage}

It is widely understood that an informant is recruited to provide information on a particular subject of interest to an agency. However, the importance of maintaining a robust overview of the actual coverage provided by informants - the extent to which informants can provide information on targets, suspects, crimes, and criminal conspiracies of interest - is perhaps less well appreciated. In the UK there is an expectation that an 'authorising officer', in managing the recruitment and deployment of informants, will be responsible for the continuous review of the extent of informant coverage set against organisational objectives and intelligence requirements (National Occupational Standards, 2013: 2). In a police service, the authorising officer will typically be a police officer of the rank of chief inspector or superintendent. This particular task of assessing informant coverage is routinely undertaken by drawing upon the expertise of subordinates; most commonly those 'handlers' and 'controllers' who are in closest proximity to the informant and the intelligence they provide. Typically, the handler will be responsible for meeting with the informants for which they have responsibility and obtaining relevant intelligence, whilst the controller will maintain a supervisory overview of this activity and coordinate the work of the handlers under her or his line management. In the police service the informant handler will typically be a police detective officer of constable rank, whilst the controller will typically be a police detective officer of inspector rank. Additionally, to support business continuity and organisational resilience, there is also oftentimes a deputy controller, usually a police detective officer of sergeant rank. Other law enforcement agencies and relevant public authorities will replicate these roles of handler, controller and authorising officer, with the duties undertaken by an appropriately qualified person from within each organisation's own particular structure. Yet, put simply, within every organisation that uses informants there will be a requirement to know how many informants there are, what exactly they can provide information on, and where there are gaps in informant coverage mapped against current and emerging priorities.

The following sections will explore approaches to the assessment and review of informant coverage in Scottish policing and law enforcement. This is achieved by drawing a somewhat artificial distinction between 'established practice' and 'emerging practice'; both of which co-exist, in a patchwork fashion, across this field. Established practice refers to the traditional and widespread approach wherein coverage is assessed by a small number of informant handlers and controllers, working in relative isolation and low-visibility in a dedicated source handling unit or similar informantfocussed environment. Emerging practice recognises the nascent development of an explicitly analytical approach to understanding informant coverage, associated with the input and support of an intelligence analyst. This new approach introduces a more systematic assessment of where coverage is and is not, and thus an evidence-base from which to indicate and prioritise areas for future action. In drawing this distinction care must be taken to ensure that this is not presented as a linear or unproblematic progression experienced universally across and within agencies. Certainly, there is nothing especially inevitable about the 'decline' of established practices or the implementation or 'success' of emergent approaches. As will be discussed, where intelligence analysts have been introduced into this area of policing and law enforcement there are some cultural factors have inhibited their effectiveness. ${ }^{6}$ Such challenges reflect many of the issues faced in integrating intelligence analysis into policing more broadly (see Brodeur and Dupont 2008; Ratcliffe, 2008; Atkinson, 2017; Belur and Johnson, 2018; Sanders and Condon, 2017). The distinction presented in this paper is therefore posited not to propose a clear break between two distinct approaches, or even to suggest a widely experienced inexorable creep from 'old' to 'new', but to instead provide a lens with which to appreciate established ways of working and to contextualise pockets of emerging practice.

\section{Established practice}

\footnotetext{
${ }^{6}$ For a discussion of such cultural dispositions in covert policing see Loftus, Goold and Mac Giollabhui (2016).
} 
A common feature of established practice in Scottish policing and law enforcement is the centrality of both the handler and the controller to the assessment of coverage provided by informants. At the very outset of a recruitment process a handler will meet the potential informant and report an evaluation of their encounter to the controller and/or deputy controller. The subsequent assessment of the potential informant is thus a collaborative process that is reliant on the both the judgement of the handler and the experience of the controller. A similar dynamic also operates once an informant has been recruited and is 'on the books' and being 'run'. As an informant handler, who had very recently moved into another area of intelligence work, remarked,

"The handler is all over the CHIS in terms of the quantity and quality of intelligence, and you had constant meetings with your controller about how things were going." (Lisa, informant handler).

As a legislative requirement the authorisation of every current informant is reviewed on a routine basis, usually quarterly, in order to ensure that the informant is being handled ethically and appropriately; a procedure that also precedes any renewal of an authorisation for a continuing informant. Within this process the informant handler and controller will each contribute to the review of a given informant, including an assessment of the nature of coverage (to what extent the informant has access to targets of interest) and frequency and quality of the reporting provided. This process benefits from the proximity of the handler to the informant and the supervisory skill of the controller: it is, after all, the handler who meets the informant in person, elicits information on behalf of the organisation, and reports this to the controller, who subsequently informs decision-making in each case, drawing upon his or her experience in this area of intelligence work. There are clear benefits of a system in which the proximity and professional judgement of the informant handler and the experience of the controller contribute to the assessment of the coverage an informant can provide. Irrespective of the long-standing and enduring debate regarding both the professional occupational status of the police officer and the professionalisation of policing (see Perrier, 1979; Holdaway, 2017) informant handlers and controllers in policing and the wider field of law enforcement are certainly specialists in their field; undergoing an extensive period of specific training for their respective roles and working with informants on a daily basis. Each handler-informed and controller-supported review of an informant and the coverage they provide is ultimately disseminated to the authorising officer for a final decision on the future status of the informant.

Yet despite the strengths of such established practice this system for assessing informant coverage does raise some issues, particularly in relation to the relatively low visibility and high autonomy of the handler role and the relationship of the handler with the informants they are responsible for running. The nature of this relationship between handler and informant has attracted some academic attention. Roger Billingsley (2003: 59), for example, has identified issues of power, professionalism, accountability, public confidence, and ethical practice as critical to such associations in policing. ${ }^{7}$ More contentiously, Billingsley also contended here that the longer the relationship between handler and informant persists, the more this develops into a 'friendship'. The existence of a precise correlation between the duration for which an informant is active and the emergence of a positive social relationship between informant and handler - that they increasingly 'like' one another - is certainly contestable: an informant may be run by a handler for some considerable period of time and no such 'friendship' develops. Discussing the nature of personal relationships with informants Dabney and Tewksbury (2016: 115) noted, based on qualitative research in the US, how officers reported it 'rare' to develop with an informant a 'true relationship built around genuine trust and feelings'. Dabney and Tewksbury do not foreclose the possibility of friendship developing in such circumstances, but instead report how the majority of officers stated strongly that maintaining a

\footnotetext{
${ }^{7}$ In his introductory text on policing Peter Joyce (2011: 29) considered how this relationship between handler and informant may possibly abet corruption.
} 
personal distance from their informants was both personally and professionally important (Dabney and Tewksbury, 2016: 121). They expanded,

Looking at informants as a resource, as a form of property, or as tools rather than necessarily as people is common and was at the core of much of the advice that experienced officers offered about informants. (Dabney and Tewksbury, 2016: 122).

Such perspectives - well-established in the existing literature (see Clark, 2001: 44) - resonated with reported experiences in Scotland. It was stressed during fieldwork that the focus for the handler should be on 'maintaining a level of rapport', where the informant is viewed not through an emotional or possessive lens, but as a covert operational asset working for the organisation and not the handler (Frank, informant controller). ${ }^{8}$ In fact, given the diverse range of (the often criminal) backgrounds of informants, handlers may have to expend extensive 'emotional labour' (see Hochschild, 1983; Taylor, 1998) to adapt to an informant's individual personality traits and social circumstances in order to elicit the valuable information that the organisation requires. ${ }^{9}$

The possibility of a developing friendship between handler and informant was nevertheless recognised by handlers as a potential risk, and highlighted during their training for the role. There was a recognition in fieldwork that the handler/informant relationship could become 'too cosy' over extended periods (Gerry, informant controller), which was why some controllers sought to 'shuffle the handler about' for particular informants (Steven, informant handler). However, there was also an awareness of the 'fine balance between not getting too close and cosy but keeping that rapport' that was critical to the process (Johnny, informant handler). Moreover, there was also a practical recognition that rotating handlers was not always possible in areas with comparatively smaller handler capacity (Peter, informant controller). Such perspectives and practices recognised the potential pitfalls of proximity as indicated by Billingsley, but worked to mitigate against the occurrence of any developing friendship. Circumstances can, however, transform the handler/informant relationship into one where the handler becomes a source of advice - on marital or personal affairs, financial or health-related matters - beyond the immediate parameters of his or her policing or law enforcement role. The provision of such advice may not indicate friendship on the part of the handler, but instead reflect a professional obligation to ensure the welfare of the informant. ${ }^{10}$

Whilst the formation of a friendship between handler and informant is both professionally discouraged and far from inevitable, what must be recognised is that there is a significant level of organisational and professional effort expended to get an individual to the point of being an active informant: from targeting, identification, and recruitment, to cultivation, authorisation, and handling. Such an expensive investment of resources and effort may, if left unchallenged, promote a degree of comfort, inertia or resistance to change; a situation that can be compounded by the occupational pressure for source units to be seen as a 'productive' in running a requisite number of 'good sources'. As Bacon (2016: 194) noted, handlers reported a 'vested career interest' in ensuring 'their sources' provided a necessary number of detections. In the US a similar perspective was recognised by Dabney and Tewksbury (2016: 128-129), who noted how officers universally viewed informants as both 'a tool' to conduct police business and 'a valued piece of personal property'. In such circumstances informant handlers may, either deliberately or inadvertently, over-value 'their own' informants and the

\footnotetext{
${ }^{8}$ Such a perspective has been recognised in the extant literature as long-established (see Clark, 2001: 44).

${ }^{9}$ The concept of emotional labour has been recently employed in the study of policing across a variety of jurisdictions (see Martin, 1999; Daus and Brown, 2012, Bhowmick and Multa, 2016; van Gelderen, Konijn and Bakker, 2016), with recent innovations in the application of the concept to civilian police staff (Lumsden and Black, 2018).

${ }^{10}$ No informants were interviewed for this study, and thus their perspective on whether the provision of such advice would be indicative of a 'friendship' remains unknown.
} 
contribution that they can make towards achieving organisational objectives. Despite a level intrusive supervision by controllers in the everyday work of their handlers - itself a challenging task as handlers work under necessary conditions of low visibility and on the basis of trust, and controllers can have a significant 'stable' (or cadre) of informants over which they are charged with maintaining oversight fieldwork disclosed a certain level of dissatisfaction amongst some senior managers with the established practice of the handler/controller monopoly on the assessment of informant coverage, as well as a recognition of the possibilities to enhance practice:

\begin{abstract}
"How do you identify gaps in coverage and how to fill those gaps? It's the fundamentals of CHIS work. We developed a targeted matrix. Handers and controllers too often focussed on what they would see and what they could get, a quick result. Sometimes their biggest driver was not the organisational need, but their own personal need or that of the CHIS. I introduced [names analyst] to work on developing that map of coverage, but only when you broke down your coverage and overlaid your crime priorities did you see where your gaps were... The whole process needs to be driven by professional competence but also analytical rigour. The analyst tells me where our strengths are and where our weaknesses are, and allows me to make decision on the best information possible." (Robert, senior police officer).
\end{abstract}

A demand thus emerged in some quarters for a more robust system where the coverage provided by informants is more transparently assessed against prioritised targets; a system in which the introduction of the civilian intelligence analyst, who is not a sworn police officer, becomes vital to organisational effectiveness.

\title{
Emerging practice
}

The introduction of civilian intelligence analysts to police informant work reflects a broader trend in policing whereby intelligence analysts, since their introduction to policing in the early 2000s following the widespread adoption of the principles of the NIM, have become the harbingers of new forms of data, methods, and information that have oftentimes challenged, and sometimes supplanted, the traditional craft, knowledge, and pragmatic approaches of police officers (see Ratcliffe, 2008; Atkinson, 2017). However, reflecting the challenges of integrating civilian intelligence analysis in other areas of policing, this recent introduction of analysts into informant work has demonstrated only limited success to date. Fieldwork indicated how, within certain parameters, intelligence analysts have been welcomed by informant handlers and controllers as an extra resource to support activity in a busy specialist police environment. Reflecting a traditional rationale for the introduction of civilian staff in policing - to 'release sworn police officers to operational duties' (see Donnelly, 2008) - the intelligence analyst has been valued from the viewpoint of providing assistance to informant handlers; freeing-up time for these police officers to engage more intensively in direct forms of handling, as opposed to the desk-based activities considered, at least culturally, as ancillary. In particular, the use of intelligence analysts for informant-targeting purposes - where analysts independently identify, through desk-based research, individuals for handlers and controllers to consider for recruitment as informants - was perhaps the contribution most valued by police officers.

"That [informant targeting] was a big part of what I did, probably the main focus. I worked most closely with the controller for targeting [and] recruitment and he was very supportive, 'cos I gave him info he needed to make decisions... I definitely saved the cops work by taking on the [informant] targeting and referral stuff." (Jack, intelligence analyst).

Such contributions could be considered as particularly valuable in an organisational context in which detectives not directly involved in informant work may lack the motivation to provide referrals to handlers in a source unit (see Bacon, 2016: 188). There are certainly opportunities for analysts to 
contribute to informant targeting, given their unique access to, and understanding of, specialist data. For example, an intelligence analyst in fieldwork (Kate) recounted her unique use of telecommunications data and social network analysis to identify potential informants for consideration for recruitment. The use of such a specialist analytical approach would generally be outside the skillset of many informant handlers.

Reflecting the scarcity of this kind of analytical support, but also the persistence of established practices, informant-targeting work is by no means monopolised by intelligence analysts. Informant handlers will often undertake basic research as part of their routine business. An informant handler, Steven, noted how he would himself proactively search intelligence databases and crime incidents to identify potential candidates for informant recruitment. Another handler similarly and straightforwardly remarked,

"We do all that ourselves [in our unit]." (Johnny, informant handler).

Nevertheless, as an area of emerging practice, the contribution of the intelligence analyst to informant-targeting work demonstrates a level of successful integration of analysis into this area of work; albeit in a context where the analyst undertakes a traditional 'support' role to the agency of the informant handler or controller. ${ }^{11}$ Crucially, however, informant-targeting work does not address a vacuum, but is instead rooted in both an appreciation of current informant coverage and an awareness of existing and developing priorities. As a controller remarked of her work and that of her handlers,

"We look at what our priorities are and what our objectives are, and we target those individuals who are ripe for recruitment." (Fiona, informant controller).

In contrast to the positive response given to analytical contributions to informant-targeting, however, integrating analysis into the assessment of informant coverage has been a more challenging task.

The move towards integrating more explicitly analytical approaches into the assessment of informant coverage has been a relatively recent development, occurring in only a limited range of settings. Where analysts have become involved in this work this has involved the direct exposure of the analyst to the organisational systems and personnel involved in informant work, and sometimes the embedding of the analyst within a relevant unit. The role of the analyst in such contexts is to harness all available data sources to provide a systematic and routinely updated account of the nature and extent of informant coverage, in order to support decision making at strategic, tactical, and operational levels. An analyst who was at the forefront of these developments in Scotland remarked that her role was to identify,

"Where are the main gaps, gaps that we have tactically and strategically and what can we do to fill that intelligence requirement from the CHIS point of view, as opposed to just doing the same old? Being at the raw source of the intelligence flow I was in a very good position to start looking at our stable of CHIS and evaluate them and see where are the huge gaps, at a strategic level." (Jennifer, intelligence analyst).

Such analytical practices and products have been of particular value to senior officers in policing; for example facilitating informed assessments on the relative health of informant stable - including the identification of gaps in coverage against prioritised targets - and supporting decision-making on which particular informants should be retained, developed or de-authorised. Additionally, the analysis

\footnotetext{
${ }^{11}$ As a counterpoint here the opportunity to engage in informant-targeting activity does provide the opportunity for the analyst to exert some indirect influence on informant recruitment, and thus (potentially) effect the shape and extent of informant coverage.
} 
of informant coverage has also proven tactically useful; supporting a more targeted approach to informant tasking,

"Whenever there is a murder, tasking goes out [to all informants]. All you are going to do is, every CHIS will want to tell you something, they don't want to tell you they don't know. So all you do is generate all this intelligence and create a load of suspects that the [senior officer in charge] can't deal with. What you need to do is look at who has got access and issue specific tasking." (Rick, senior police officer).

Such approaches can prevent the largely unnecessary generation of intelligence that can result from the 'blanket' approaches often undertaken in response to a major crime or incident, as well as encouraging the deployment of informants across geographic boundaries and areas of criminality; which also results in the development of the individual informant themselves. Rigorous and timely analysis of informant coverage can be critical in supporting such targeted tasking and informant development practices. However, there was a recognition in fieldwork that the success of analyst involvement in the assessment of informant coverage was contingent upon the particular type of analyst deployed to the task, with their cultural legitimacy and integration depending on both their experience and training.

The general inadequacies and variances in training for intelligence analysts in the UK and beyond, and the consequences of this for the proficiency, esteem, and integration of analysts in policing, has been well-documented (see Belur and Johnson, 2018: 781-782; Ratcliffe, 2016: 188; Evans and Kebbell, 2012: 216-217). The lack of appropriate training courses for intelligence analysts in the new specialism of informant-related work is therefore unsurprising. In response to this professional lacuna intelligence analysts have, by way of example, sometimes resorted to 'shadowing' courses delivered to police officers - such as those focussed upon issues such as informant-targeting, or the roles of informant handler or controller - in order to address their knowledge and skills gaps. ${ }^{12}$ Additionally, there have been attempts at self-professionalisation in Scotland. A useful example in this regard was the CHIS Analyst Practitioners Group (CHIS APG), which operated in the early 2010s under the previous arrangements for Scottish policing and law enforcement. The former Lothian and Borders Police force, now superseded by a national police force, led on use of analysts in this area, with 'CHIS analysts' active in both informant-targeting and the assessment of source coverage. The CHIS APG proactively sought to create a network of analysts engaged in informant work from across the Scottish policing landscape, with a view to sharing best practice and problem solving around shared concerns (Lothian and Borders Police, 2012). A key concern centred upon the paucity of appropriate training, but also the lack of a commonly-shared, well-recognised, rigorous and robust methodology to underpin everyday practice. Analysts were left to devise such methodologies themselves:

"I came up with a simple way of scoring CHIS coverage of each SOCG [serious organised crime group], based on the number and quality of sources [informants] reporting on members of the group. The weak point in that method was assessing the quality of their intel. Handlers and controllers naturally had a strong sense of that, although they were probably biased towards thinking the intel was good, especially for longstanding CHIS." (Jack, intelligence analyst).

The CHIS APG in Scotland was limited by its informal nature; and the emergence of 'CHIS analysis' as an embedded specialism withered as the move towards a single national police force progressed. Pockets of practice are likely to remain in particular business areas of policing and law enforcement in

\footnotetext{
12 Interestingly, handlers and controllers in fieldwork repeatedly remarked quite positively on the quality and utility of their training.
} 
Scotland; however, the deployment of analysts to such roles is best characterised as the exception rather than the rule.

\section{Discussion}

With or without analytical support it is reasonable to assert that the use of informants in policing and law enforcement will remain common practice, particularly in high policing where it has deep roots. Such a conservative assertion seems uncontroversial: research in the UK has indicated that practitioners consider informants to be one of the most important and trusted intelligence sources in policing (Kleiven, 2006: 257) and 'an effective source of information by those in law enforcement' (Clark, 2007: 431-432). For Bacon (2016: 172-179) drug detectives in the UK coveted information from informants, whom they placed 'on a pedestal' given the value of the information they can provide. Even more recently James et al (2017: 81-82) highlighted informants as the most prized intelligence stream in policing. Fieldwork for this paper highlighted similar sentiments, with informants valued for their provision of unique information, often in real-time. Situating the value of informants in a more economic context a handler (Johnny) highlighted the cost-effectiveness of deploying informants in operations and investigations, particularly when compared to other resource intensive forms of intelligence collection, such as surveillance. Whilst there is an opportunity-cost to be considered here - just as surveillance requires the labour of a large team, a similar dynamic is also at play in the police informant environment, where 'cost' extends beyond simply 'what the informant is paid' (Dunnighan and Norris, 1999) - such perspectives were common in fieldwork. Johnny further noted how intelligence from informants provided 'outstanding' value-for-money, and the outcomes from whom - particularly in the ability to disrupt criminal activity before any offence occurred - were recognised as excellent by senior management.

Nevertheless, it must be recognised that informants are only one intelligence stream of many in contemporary policing; with alternatives including information from members of the public, frontline police officers and law enforcement professionals, technical assets, and surveillance resources. ${ }^{13}$ Moreover, the increasing exploitation by the police and law enforcement agencies of publicly available 'open sources' - including intelligence gleaned from social media - has been widely noted in the literature (see Staniforth, 2017; Ingle and Staniforth, 2017; Gibson, 2014a; Omand, 2017). This rise of open source intelligence has undoubtedly provided new and alternative sources of intelligence to tackle crime, with some concomitant impact on the use of informants. ${ }^{14}$ Yet, reflecting a wider set of cultural dispositions, it has been noted in the literature how open source intelligence is often regarded as 'less equal' than other, covert sources of intelligence; when, it is argued, it should be considered complimentary to such clandestine sources (Gibson, 2014b: 11-12). Irrespective of disparate occupational tendencies to favour one particular intelligence stream over another, in the organisational context of a move towards a pluralistic and synergetic 'all-source fusion' approach to intelligence work (see Russell, 2007; Sims, 2007; Day, Gibson and Ramwell, 2017) the ethical, proportionate, efficient, and effective use of informants will still remain important in tackling increasingly complex crimes (see Gioe, 2017). In other words, within a system that seeks to develop and exploit a plurality of sources, intelligence from informants will remain of considerable value.

Care is also required to ensure that the cultural environment is suitable for the integration of analysis and intelligence analysts in this area of policing. As Jerry Ratcliffe (2008: 215) has asserted, in the context of attempts to integrate the 'old knowledge' of cops and the 'new knowledge' of analysts in intelligence-led policing, the power of the culture of police officers has the potential to marginalise the intelligence analyst and their function. Moreover, recent research in Scottish policing has

\footnotetext{
${ }^{13}$ Over two decades ago Steven Greer (1995: 514) noted that informants were even at this time 'merely cogs', although vital ones, 'in a complex intelligence-gathering system'.

${ }^{14}$ Particularly in the preliminary stages of an investigation or operation, where open source intelligence may be an alternative or supplementary means of intelligence development.
} 
highlighted how the integration of intelligence analysts into police intelligence work has been inhibited by the infantilisation of the analyst; a process interwoven with the patriarchal dispositions within police culture and the emergence of a gender order in policing that subordinates femininity, youth and other masculinities that run counter to police culture's form of hegemonic masculinity (Atkinson, 2017). Any cultural resistance may also be compounded by the fact that analysts are frequently considered to be working to the agenda of police leaders and management, rather than operational police officers (see Evans and Kebbell, 2012, John and Maguire, 2007: 208-209). Given such challenges, and recognising the forms of cultural capital (see Bourdieu, 1997: 47) that are both valued and valuable in policing, fieldwork clearly disclosed several requirements, including: a clear vision of the exact rationale for, and remit of, an intelligence analyst in such an environment; appropriate 'buy-in' from operational police officers (handlers and controllers); and the selection of a suitably experienced analyst in this role.

\section{Conclusion}

This paper has explored how informant coverage - the extent to which informants can provide information on targets, suspects, crimes, and criminal conspiracies - has recently been assessed in Scotland. It has drawn a distinction between established and emergent practices; highlighting the strengths and limitations of traditional approaches and the promise and pitfalls of analysis, and the contribution of the intelligence analyst, in this specialist area of intelligence work. Bringing analysis to bear on informant work, if it is rooted in a consistent, robust and well-understood methodology, can add value to other areas of innovative policing that require an understanding of how effectively policing and law enforcement agencies are positioned to mitigate criminal threats, such as serious organised crime group mapping (see Hamilton-Smith and Mackenzie, 2010; Cavanagh, HamiltonSmith and Mackenzie, 2015; National Crime Agency, 2018). Yet it must also be recognised that the emergence of such new practices in the assessment of informant coverage in Scotland has been, to date, patchy at best; varying between agencies, and with some business areas developing an informant-focussed analytical capability at a faster rate than others. If analysis, and intelligence analysts, are to make a valuable and sustainable contribution to the understanding of informant coverage in policing and law enforcement then proactive leadership will be required for its consistent implementation, ongoing support, and future success. In the absence of such leadership this emerging practice, and its inherent promise, will risk future atrophy.

In conclusion, this paper has addressed, at least in part, the claim of Loftus and Goold (2012: 278 ) that there is a pressing need for empirical research into the everyday practices of covert police surveillance, including issues concerning the use of informants. Beyond the aforementioned factors that limit generalisation there are also issues inherent in the sample that qualify the overall findings. Perhaps most pressingly, the sample contains both current and former practitioners in this field, so the voices and experiences expressed may not always reflect current practices at the cutting edge of policing and law enforcement. Relatedly, the relatively small sample - 19 people from two current agencies (and some precursor organisations) - may not fully capture the range of views across the diverse array of agencies with an informant capability in the broad field of Scottish policing and law enforcement. Such issues, however, are tempered by the paucity of existing research in this subject area and the exploratory nature of the research itself. The findings thus represent a valuable initial appraisal of the issues affecting this area of intelligence work, and a solid foundation for future enquiry and reflections on practice. 


\section{References}

Atkinson, C. (2017). Patriarchy, gender, infantilisation: A cultural account of police intelligence work in Scotland. Australian \& New Zealand Journal of Criminology, 50(2): 234-251.

Bacon, M. (2016). Taking Care of Business: Police Detectives, Drug Law Enforcement and Proactive Investigation. Oxford: Oxford University Press.

Bean, P. and Billingsley, R. (2001). Drugs, crime and informers. Clark, R. (2001). Informers and corruption. In: Billingsley, R., Nemitz, T. and Bean, P. (Eds.) Informers: Policing, Policy, Practice. London: Routledge.

Bell, J.B. (1993). The Irish Troubles: A Generation of Violence 1967-1992. Dublin: Gill \& Macmillan.

Belur, J. and Johnson, S. (2018). Is crime analysis at the heart of policing practice? A case study. Policing \& Society, 28 (7): 768-786.

Bhowmick, S. and Multa, Z. (2016). Emotional labour of policing: does authenticity play a role? International Journal of Police Science \& Management, 18 (1): 47-60.

Billingsley, R., Nemitz, T. and Bean, P. (2001). Introduction. In: Billingsley, R., Nemitz, T. and Bean, P. (Eds.) Informers: Policing, Policy, Practice. London: Routledge.

Billingsley, R. (2003). The police informer/handler relationship: Is it really unique? International Journal of Police Science \& Management, 5 (1): 50-62.

Billingsley, R. (2009a). Risk management. In: Billingsley, R. (Ed.) Covert Human Intelligence Sources: The 'Unlovely' Face of Police Work. Hook: Waterside Press.

Billingsley, R. (2009b). The informer relationship. In: Billingsley, R. (Ed.) Covert Human Intelligence Sources: The 'Unlovely' Face of Police Work. Hook: Waterside Press.

Bloom, RM. (2002). Ratting: The Use and Abuse of Informants in the American Justice System. London: Praeger.

Bourdieu, P. (1997). The forms of capital. In: Halsey, A., Lauder, H., Brown, P. and Wells, AS. (Eds.) Education: Culture, Economy, Society. Oxford: Oxford University Press.

Brodeur, JP. (2007). High and low policing in post-9/11 times. Policing: A Journal of Policy and Practice, 1 (1): 25-37.

Brodeur, J. and Dupont, B. (2008). Introductory essay: the role of knowledge and networks in policing. In: Williamson, T. (Ed.) The Handbook of Knowledge-Based Policing. Chichester: John Wiley and Sons.

Burcher, M. and Whelan, C. (2018). Intelligence-led policing in practice: reflections from intelligence analysts. Police Quarterly, OnlineFirst. Available at: https://doi.org/10.1177/1098611118796890 [Accessed 22 December 2018].

Cavanagh, B., Hamilton-Smith, N. and Mackenzie, S (2016). Organised crime in Scotland and the criminal justice response. In: Croall, H., Mooney, G., Munro, M. (Ed.). Crime, Justice and Society in Scotland. Abingdon: Routledge. 
Charters, DA. (2012). 'Have a go': British Army/MI5 agent-running operations in Northern Ireland, 1970-72. Intelligence and National Security, 28 (2): 202-229.

Clark, D. (2007). Covert surveillance and informer handling. In: Newburn, T., Williamson, T. and Wright, A. (Eds.) Handbook of Criminal Investigation. Abingdon: Willan.

Clark, R. (2001). Informers and corruption. In: Billingsley, R., Nemitz, T. and Bean, P. (Eds.) Informers: Policing, Policy, Practice. London: Routledge.

Cochrane, M. and Monaghan, R. (2012). Countering terrorism through the use of informants: the Northern Ireland experience. Behavioral Sciences of Terrorism and Political Aggression, 4 (1): 26-40.

Cooper, P. and Murphy, J. (1997). Ethical approaches for police officers when working with informants in the development of criminal intelligence in the United Kingdom. Journal of Social Policy, 26 (1): 120.

Coogan, TP. (1996). The Troubles: Ireland's Ordeal 1966-1996 and the Search for Peace. London: Arrow.

Crous, C. (2009). Human intelligence sources: challenges in policy development. Security Challenges, 5 (3): 117-127.

Crous, C. (2011). Managing covert human intelligence sources: lessons for police commanders. Australasian Policing, 3 (2): 12-15.

Cummings, I., Foley, M. and King, M. (2014). '... And after the break': police officers' views of TV crime drama. Policing: A Journal of Policy and Practice, 8 (2): 205-211.

Daus, CS. and Brown, S. (2012). The emotion work of police. In: Ashkanasy, NM., Zerbe, WJ. and Härtel, CEJ. (Eds.) Research on Emotion in Organizations Volume 12: Emotions and Organizational Governance. Bingley: Emerald Group Publishing.

Dabney, DA. and Tewksbury, R. (2016). Speaking Truth to Power: Confidential Informants and Police Investigations. Oakland, California: University of California Press.

Day, T., Gibson, H. and Ramwell, S. (2017). Fusion of OSINT and non-OSINT data. In: Akhgar, B., Bayerl, PS. and Sampson, F. (Eds.) Open Source Intelligence Investigation: From Strategy to Implementation. Cham: Springer.

Donnelly, D. (2008). Community wardens in Scotland: practitioners' views. The Howard Journal of Criminal Justice, 47 (4): 371-382.

Dunnighan, C. and Norris, C. (1999). The detective, the snout, and the Audit Commission: the real costs in using informants. The Howard Journal of Crime and Justice, 38 (1): 67-86.

Eterno, JA., Verma, A. and Silverman, EB. (2016). Police manipulations of crime reporting: insiders' revelations. Justice Quarterly, 33 (5): 811-835.

Evans, JM. and Kebbell, MR. (2012) The effective analyst: a study of what makes an effective crime and intelligence analyst. Policing \& Society, 22 (2): 204-219. 
Fitzpatrick, B. (2009). Immunity from the law: participation in crime and the scope of liability. In: Billingsley, R. (Ed.) Covert Human Intelligence Sources: The 'Unlovely' Face of Police Work. Hook: Waterside Press.

Fondevila, G. (2013). Controlling the Madrinas: the police informer management and control system in Mexico. The Police Journal: Theory, Practice and Principles, 86 (2): 116-142.

Gibson, SD. (2014a). Open source intelligence. In: Dover, R., Goodman, MS. and Hillebrand, C. (Eds.) Routledge Companion to Intelligence Studies. Abingdon: Routledge.

Gibson, SD. (2014b). Exploring the role and value of open source intelligence. In: Hobbs, C., Moran, M. and Salisbury, D. (Eds.) Open Source Intelligence in the Twenty-First Century New Approaches and Opportunities. London: Palgrave Macmillan.

Gill, P. (1998). Making sense of police intelligence? The use of a cybernetic model in analysing information and power in police intelligence processes. Policing \& Society, 8 (3): 289-314.

Gill, P. (2009). Security intelligence and human rights: illuminating the 'heart of darkness'? Intelligence and National Security, 24 (1): 78-102.

Gioe, DV. (2017). 'The more things change': HUMINT in the cyber age. In: Dover, R., Dylan, H. and Goodman, MS. (Eds.) The Palgrave Handbook of Security, Risk and Intelligence. London: Palgrave Macmillan.

Greer, S. (1995). Towards a sociological model of the police informant. The British Journal of Sociology, 46 (3): 509-527.

Hamilton-Smith, N. and Mackenzie, S. (2010). The geometry of shadows: a critical review of organised crime risk assessments. Policing \& Society, 20 (3): 257-279.

Harfield, C. (2009). The regulation of CHIS. In: Billingsley, R. (Ed.) Covert Human Intelligence Sources: The 'Unlovely' Face of Police Work. Hook: Waterside Press.

Hochschild, AR. (1983). The Managed Heart: The Commercialisation of Human Feeling. Berkeley: University of California Press.

Holdaway, S. (2017). The re-professionalization of the police in England and Wales. Criminology \& Criminal Justice, 17(5) 588-604.

Home Office. (2018). Covert Human Intelligence Sources Revised Code of Practice. Available at: https://assets.publishing.service.gov.uk/government/uploads/system/uploads/attachment data/file 733220/20180802 CHIS code reformatted for publication 002 .pdf [Accessed 22 December 2018].

Ingle, T. and Staniforth, A. (2017). Horizon scanning for law enforcement agencies: identifying factors driving the future of organized crime. In: Larsen, HL., Blanco, JM., Pastor, RP. and Yager, RR. (Eds.) Using Open Data to Detect Organized Crime Threats: Factors Driving Future Crime. Cham: Springer International Publishing.

Innes, M. (2000). Professionalizing the role of the police informant: the British experience. Policing \& Society, 9 (4): 357-383. 
James, A. (2016). Understanding Police Intelligence Work. Bristol: Polity Press.

James, A., Phythian, M., Wadie, F. and Richards, J. (2017). The road not taken: understanding barriers to the development of police intelligence practice. The International Journal of Intelligence, Security, and Public Affairs, 19 (2): 77-91.

John, T. and Maguire, M. (2007). Criminal intelligence and the National Intelligence Model. In: Newburn, T., Williamson, T. and Wright, A. (Eds.) Handbook of Criminal Investigation. Cullompton: Willan.

Joyce, P. (2011). Policing: Development and Contemporary Practice. London: SAGE.

Kleiven, ME. (2006). Where's the intelligence in the National Intelligence Model? International Journal of Police Science \& Management, 9 (3): 257-273.

Loftus, B. and Goold, B. (2012). Covert surveillance and the invisibilities of policing. Criminology \& Criminal Justice, 12 (3): 257-273.

Loftus, B., Goold, B. and Mac Giollabhui, S. (2016). From a visible spectacle to an invisible presence: the working culture of covert policing. The British Journal of Criminology, 56 (4): 629-645.

Lowe, D. (2011). The lack of discretion in high policing. Policing \& Society, 21 (2): 233-247.

Lowe, D. (2015). Handling informers. In: Eterno, JA. and Roberson, C. (Eds.) The Detective's Handbook. London: CRC Press.

Lothian and Borders Police. (2012). Thematic inspection updates. Available at: http://www.edinburgh.gov.uk/download/meetings/id/37003/audit and scrutiny committee - 0511-12 - full meeting papers [Accessed 22 December 2018].

Lumsden, K. and Black, A. (2018). Austerity policing, emotional labour and the boundaries of police work: an ethnography of a police force control room in England. British Journal of Criminology, 58 (3): 606-623.

Mac Giollabhuí, S., Goold, B. and Loftus, B. (2016). Watching the watchers: conducting ethnographic research on covert police investigation in the United Kingdom. Qualitative Research, 16 (6): 630-645.

MacVean, A. and Neyroud, P. (2012). Police Ethics and Values. London: SAGE.

Manning, PK. (1977). Police Work: The Social Organization of Policing. Cambridge: MIT Press.

Manning, PK. (1978). The police: mandate, strategies, and appearances. In: Manning, PK. and van Maanen, J. (Eds.) Policing: A View from the Street. California: Goodyear.

Manning, PK. (2016). Democratic Policing in a Changing World. Abingdon: Routledge.

Martin, SE. (1999). Police force or police service? Gender and emotional labor. The Annals of the American Academy of Political and Social Science, 561 (1): 111-126. 
Matchett, WR. (2017). Terrorism and counterterrorism: the criticality of context. In: Romaniuk, SN., Grice, F., Irrera, D. and Webb, S. (Eds.). The Palgrave Handbook of Global Counterterrorism Policy. London: Palgrave Macmillan.

Miller, JM. (2011). Becoming an informant. Justice Quarterly, 28 (2): 203-220.

Miller, JM. and Selva, LH. (1994). Drug enforcement's doubleedged sword: An assessment of asset forfeiture programs. Justice Quarterly, 11 (2): 313-335.

Moran, J. (2010). Evaluating Special Branch and the use of informant intelligence in Northern Ireland. Intelligence and National Security, 25 (1): 1-23.

National Crime Agency. (2018). National Strategic Assessment of Serious and Organised Crime 2018. Available at: http://nationalcrimeagency.gov.uk/publications/905-national-strategic-assessment-forsoc-2018/file [Accessed 22 December 2018].

National Occupational Standards. (2013). SFJCG106 Manage and control the recruitment and deployment of covert human intelligence sources (CHIS). Available at: https://www.ukstandards.org.uk/PublishedNos-old/SFJCG106.pdf [Accessed 4 December 2018].

Newburn, T. (2011). Understanding investigation. In: Newburn, T., Williamson, T. and Wright, A. (Eds.). Handbook of Criminal Investigation. London: Routledge.

Norris, C. and Wilson, D. (2016). Introduction. In: Norris, C. and Wilson, D. (Eds.) Surveillance, Crime and Social Control. Abingdon: Routledge.

Office of Surveillance Commissioners. (2016). Annual Report of the Chief Surveillance Commissioner to the Prime Minister and to the Scottish Ministers for 2015-2016. London: Office of Surveillance Commissioners.

Omand, D. (2006). Ethical guidelines in using secret intelligence for public security. Cambridge Review of International Affairs, 19 (4): 613-628.

Omand, D. (2017). Social media intelligence (SOCMINT). In: Dover, R., Dylan, H. and Goodman, MS. (Eds.) The Palgrave Handbook of Security, Risk and Intelligence. London: Palgrave Macmillan.

Perrier, DC. (1979). Is policing a profession? Canadian Journal of Criminology, 21 (1): 52-70.

Punch, M. (1979). Policing the Inner City: A Study of Amsterdam's Warmoesstraat. London: Macmillan.

Rajakaruna, N., Henry, P., Crous, C. and Fordham, A. (2013). Community intelligence: exploring human source as a new frontier. Australasian Policing, 5 (1): 19-22.

Ratcliffe, JH. (2002). Intelligence-led policing and the problems of turning rhetoric into practice. Policing \& Society, 12 (1): 53-66.

Ratcliffe, JH. (2005). The effectiveness of police intelligence management: a New Zealand case study. Police Practice \& Research, 6 (5): 435-451.

Ratcliffe, J. (2008). Knowledge management challenges in the development of intelligence-led policing. In: Williamson, T. (Ed.) The Handbook of Knowledge-Based Policing. Chichester: John Wiley and Sons. 
Ratcliffe, J. (2016). Intelligence Led Policing. Abingdon: Routledge.

Russell, RL. (2007). Achieving all-source fusion in the intelligence community. In: Johnson, LK. (Ed.) Handbook of Intelligence Studies. London: Routledge.

Sanders, C. and Condon, C. (2017). Crime analysis and cognitive effects: the practice of policing through flows of data. Global Crime, 18 (3): 237-255.

Schreiber, AJ. (2001). Dealing with the devil: an examination of the FBI's troubled relationship with its confidential informants. Columbia Journal of Law and Social Problems, 34 (4): 301-368.

Shane, J. (2016). Confidential Informants: A Closer Look at Police Policy. London: Springer.

Sheptycki, J. (2004). Organizational pathologies in police intelligence systems: some contributions to the lexicon of intelligence-led policing. European Journal of Criminology, 1 (3): 307-332.

Sheptycki, J. (2007). Police ethnography in the house of serious and organized crime. In: Henry, A. and Smith, DJ. (Eds.). Transformations of Policing. Aldershot: Ashgate.

Sims, J. (2007). Intelligence to counter terror: the importance of all-source fusion. Intelligence and National Security, 22 (1): 38-56.

Skolnick, J. (2011). Justice without Trial: Law Enforcement in Democratic Society. New Orleans: Quid Pro Books.

Spalek, B. (2014). Community engagement for counterterrorism in Britain: an exploration of the role of "connectors" in countering takfiri jihadist terrorism. Studies in Conflict \& Terrorism, 37 (10): 825841.

Staniforth, A. (2017). Police use of open source intelligence: the longer arm of law. In: Akhgar, B., Bayerl, PS. and Sampson, F. (Eds.) Open Source Intelligence Investigation: From Strategy to Implementation. Cham: Springer.

Taylor, SE. (1998). Emotional labour and the new workplace. In: Thompson, P. and Warhurst, C. (Eds.) Workplaces of the Future. Basingstoke: Palgrave.

van Gelderen, BR., Konijn, EA. and Bakker, AB. (2016). Emotional labor among police officers: a diary study relating strain, emotional labor, and service performance. The International Journal of Human Resource Management, 28 (6): 852-879.

Williamson, T. (2008). Introduction to the handbook. In: Williamson, T. (Ed.) The Handbook of Knowledge-Based Policing: Current Conceptions and Future Directions. Chichester: John Wiley \& Sons.

Williamson, T. and Bagshaw, W. (2001). The ethics of informer handling. In Billingsley, R., Nemitz, T. and Bean, P. (Eds.) Informers: Policing, Policy, Practice. London: Routledge.

Wool, GJ. (1985). Police informants in Canada: the law and reality. Saskatchewan Law Review, 50 (2): 249-270. 